\title{
SPRAWOZDANIE Z OGÓLNOPOLSKIEJ KONFERENCJI STUDENTÓW I DOKTORANTÓW PRZEMOC W ŻYCIU PUBLICZNYM - PERSPEKTYWA FILOZOFICZNA, POLITYCZNA I HISTORYCZNA, WYDZIAŁ FILOZOFII CHRZEŚCIJAŃSKIEJ UKSW, WARSZAWA, 24 MAJA 2017 R.
}

24 maja 2017 roku na Wydziale Filozofii Chrześcijańskiej Uniwersytetu Kardynała Stefana Wyszyńskiego w Warszawie odbyła się ogólnopolska konferencja studentów i doktorantów, zatytułowana Przemoc w życiu publicznym - perspektywa filozoficzna, polityczna i historyczna. Konferencja została zorganizowana przez Koło Naukowe Studentów Filozofii UKSW. Członkowie KNSF każdego roku starają się stworzyć studentom i doktorantom przestrzeń do przedstawienia w szerszym gronie swoich naukowych refleksji i badań. W tym roku odbyły się trzy sesje prowadzone przez członków KNSF, w ramach których zaprezentowano dwanaście referatów. Spotkanie zgromadziło przedstawicieli różnych polskich środowisk akademickich (Uniwersytet Warszawski, Uniwersytet Łódzki, Katolicki Uniwersytet Lubelski, Akademia im. Jana Długosza w Częstochowie, Akademia Pedagogiki Specjalnej w Warszawie).

Zebranych w auli im. R. Schumana gości i prelegentów powitał student Instytutu Filozofii UKSW Michał Kowalski, prezes Koła Naukowego Studentów Filozofii, który przypomniał, że przemoc wciąż niestety stanowi nieodłączny element życia publicznego, choć na przestrzeni lat zmieniła ona swoje formy. Ukazaniu wieloaspektowości problemu przemocy służyć ma - mówił prezes KNSF organizowane $\mathrm{w}$ filozoficznym środowisku młodych naukowców tegoroczne spotkanie. Otwarcia konferencji dokonał ks. dr hab. 
Jacek Grzybowski, opiekun Koła Naukowego Studentów Filozofii. W swoim wystąpieniu zwrócił uwagę na aktualność problemu przemocy w dzisiejszym świecie. Zauważył, że obecnie właściwie każdy człowiek spotyka się z jakimś rodzajem przymusu bądź bezprawia, który choć nie zawsze ma charakter fizyczny, przybiera różnorodne, ale realne formy - mobbing, przemoc językowa czy wulgarność i nienawiść związane $z$ aktywnością internetową. Coraz częściej podnoszony zostaje obecny zawsze w ludzkiej historii, ale dziś wybrzmiewający zupełnie na nowo, problem stosunków między państwem a obywatelem. Czy państwo może stosować przemoc wobec obywatela? Ks. Grzybowski zwrócił również uwagę na zagrożenia będące konsekwencją postępującego rozwoju technologicznego, czego najbardziej widocznym przykładem jest powszechny i nieustanny monitoring. Czy obserwowanie obywateli zarówno w codziennych, jak i intymnych sytuacjach, czytanie prywatnych maili czy inwigilacja środowisk alternatywnych przez władze państwa mogą być działaniami usprawiedliwianymi w imię wspólnego dobra? Zauważył, że globalną dyskusję wywołują, zapoczątkowane w XXI wieku atakiem na World Trade Center w Nowym Jorku, coraz częstsze ataki terrorystyczne. Wszechobecność przemocy w życiu publicznym domaga się więc rozpatrzenia tego zagadnienia w sposób szeroki i możliwie wielokierunkowy. Przed tym zadaniem - zaznaczył ks. Grzybowskistają uczestnicy konferencji zorganizowanej na Wydziale Filozofii Chrześcijańskiej.

Sesję przedpołudniową prowadziła studentka Instytutu Filozofii UKSW Natalia Nejman z KNSF. Obrady rozpoczął ks. prof. dr hab. Piotr Mazurkiewicz z Instytutu Politologii UKSW wygłaszając wykład Czy biedne, nagie, drżqce diabty sq zatożycielami cywilizacji? Tytuł wystąpienia nawiązywał do tekstów Leo Straussa, jednego $\mathrm{z}$ ważniejszych filozofów polityki XX wieku, ukazującego istotę Hobbsowskiej idei politycznej. Prelegent w panoramicznym obrazie historii polityki przypomniał, że Arystoteles traktował politykę jako sztukę wymagającą namysłu teoretycznego i wiedzy praktycznej. 
Jego zdaniem polityka powinna być nastawiona na realizację dobra wspólnego bez użycia siły fizycznej, a jej rezultat powinna stanowić nowa rzeczywistość społeczna wykreowana w sposób wolny, ale nie dowolny. Od przyjęcia tej teleologicznej wizji daleki był Niccolò Machiavelli. Według niego polityka jest techniką sprawowania władzy, dzięki której człowiek może zrealizować kierujący nim naczelny impuls - pragnienie chwały. U podstaw tak skonstruowanej polityki odnajdujemy nie pragnienie cnoty, a raczej rodzaj zbrodni założycielskiej. Inną wizję antropologiczną przyjmował brytyjski myśliciel polityczny Thomas Hobbes. Uznając człowieka za złego z natury, stwierdzał, że to strach przed śmiercią oraz przemocą ze strony innych jest fundamentem życia politycznego. Polityka i państwo są po to, by zmniejszyć lęk. Zdaniem Hobbesa zamiast bowiem bać się wszystkich, lepiej bać się jednego podmiotu, czyli państwa. Jeszcze inną teorię polityczności zaproponował angielski empirysta John Locke, który twierdził, że ludzie mogliby żyć bez państwa, ale byłoby to życie niewiele warte. Według Locke'a, znamienne dla człowieka pragnienie komfortu sprawia, że ludzie dążą do zastąpienia polityki ekonomią. Prof. Mazurkiewicz zauważył, że myśl oświeceniowa wiąże realizację dobra wspólnego $\mathrm{z}$ instytucjami, a nie z cnotą obywateli. Na potwierdzenie swoich słów przywołał metaforę Immanuela Kanta, do której nawiązywał Strauss, a wedle której można za realne do wyobrażenia uznać społeczeństwo złożone z diabłów. W społeczności rozumnych diabłów instytucje działają dobrze niezależnie od motywacji, jakimi kierują się obywatele. Według filozofa z Królewca eliminacja przemocy nastąpi tylko wtedy, gdy odwołamy się do ekonomii, a dokładnie, gdy dokona się przeniesienie na płaszczyznę ludzkich działań stosunków między sferą produkcji a sferą konsumpcji. Dopiero taka postawa doprowadzi ludzi do rezygnacji z przemocy w imię osiągnięcia nadrzędnego celu, jakim będzie spełnienie wspólnych pragnień. Jak zaznaczył ks. prof. Mazurkiewicz, w przedstawionych koncepcjach polityki istotna okazywała się przyjęta przez ich twórców antropologia. Negatywna - skutkuje społeczeństwem 
kontroli i przymusu, absolutnie pozytywna - ociera się o nierealność utopi. Jedynie w chrześcijańskiej antropologii, zauważył prelegent, ludzie nie są postrzegani skrajnie - ani jako aniołowie, ani jako diabły. Chrześcijaństwo, zakładając dobrą wolę ludzi, pamięta, że czasem bywają oni źli i przewrotni.

Drugi wykład zaprezentował mgr Paweł Rzewuski z Uniwersytetu Warszawskiego. Prelegent w referacie Sarmacka ontologia polityki skoncentrował się na opisaniu ważnych dla I Rzeczpospolitej trzech stanów sejmujących - Król, Sejm i Senat - które wykrystalizowały się po pierwszym polskim bezkrólewiu, a których polityczne kompetencje przez wiele dziesięcioleci pozostawały nierozstrzygnięte. Ta historyczna sytuacja spowodowała, że ustrój, który teoretycznie miał zapewnić pokój, stał się w Polsce Piastów i Jagiellonów przyczyną bardzo wielu konfliktów. Stąd w XVI i XVII wieku wszechobecna była przemoc bezpośrednia. Jej przejawem były między innymi rokosze, czyli zbrojne wystąpienia przeciwko królowi, które niekiedy przeradzały się w otwarte wojny domowe. Nierzadkie były przypadki przekupywania przez bogatych chłopów ubogich szlachciców, którzy mieli prawo głosu. Wszystko po to, by przekupieni wyżsi stanem obywatele głosowali tak, jak pragnęły tego stany niższe. Słynne liberum veto $\mathrm{w}$ rzeczywistości zaczęło stanowić mechanizm narzucający wolę jednostki woli ogólu. Sarmatyzm - obecna w Rzeczpospolitej Obojga Narodów formacja kulturowa - wiązał się ściśle ze świadomym przeżywaniem polityki, rozumianej jako nieustanne ścieranie się racji, pojawienie się konfliktów i wypracowywanie konsensusu. Mgr Rzewuski stwierdził, że świadomość praktyki i teorii myśli politycznej I Rzeczpospolitej jest kluczowa dla zrozumienia całej polskiej tradycji politycznej i wynikającego z niej dzisiejszego kształtu życia społecznego.

Jako trzeci prelegent w sesji przedpołudniowej swój referat Seksualnośc jako narzędzie sprawowania wtadzy wygłosił Filip A. Jach z Uniwersytetu Łódzkiego. Starał się pokazać, że mamy obecnie do czynienia $\mathrm{z}$ intrygującym paradoksem - seks jest obecny w życiu 
publicznym, choć w życiu rodzinnym pozostaje często tematem tabu. Sytuacja ta pozwala na wykorzystanie seksualności jako narzędzia sprawowania władzy na dwa sposoby: zarówno poprzez eksponowanie seksu oraz ukrywanie go. W tym kontekście prelegent przywołał badania austriackiego psychoanalityka Wilhelma Reicha i wynikającą z nich jego koncepcję biopolityki, zgodnie z którą życiem publicznym zarządza się poprzez regulację biologicznej energii. W teorii stworzonej przez Reicha jednostka kumuluje swą witalność, która uwalniana jest jedynie poprzez akty seksualne. Zarówno marketing, skupiający się na kreowaniu potrzeb seksualnych, jak i tłumienie zachowań seksualnych w rodzinie, powodują powstanie frustracji i agresji. Jach porównał tę sytuację do obecnego w tragedii greckiej nieuchronnego fatum, z tym wyjątkiem, że nie jest już ono rezultatem gry mitologicznych bogów, a instynktów i popędów człowieka. Jedyne rozwiązanie tego problemu to - zdaniem mówcy - zapewnienie społeczeństwu szerokiej i rzetelnej edukacji seksualnej.

Przemoc oswojona? - ostatni referat w sesji przedpołudniowej wygłosił mgr Maciej Talaga ze Stowarzyszenia na rzecz Dawnych Europejskich Sztuk Walki ARMA-PL. Prelegent rozpoczął swe wystąpienie od stwierdzenia, że przemoc i walka są ze sobą nierozerwalnie związane. Obecnie przemoc jest uznawana za coś z gruntu negatywnego, inaczej jednak postrzegana była w średniowieczu, gdy dokonało się pewne jej zinstytucjonalizowanie. W każdym większym średniowiecznym mieście był bowiem człowiek pełniący funkcję kata, a torturowanie ludzi nie wywoływało zdziwienia czy oburzenia. Częste konflikty zbrojne i rozbójnictwo spowodowały, że ludzie wieków średnich zaczęli myśleć o środkach zaradczych, które pomogłyby ograniczyć przemoc bądź stanowić obronę przed nią. Ta społeczna potrzeba sprawiła, że pojawili się wędrowni zawodowi nauczyciele walki - fechtmistrzowie - pokazujący, jak konieczna jest w czasach walk i rabunków edukacja wojenna. Maciej Talaga, przedstawiając ciekawy materiał historyczny, wyjaśnił, że średniowieczny projekt treningu powszechnego nie spełnił jednak pokładanych w nim nadziei. 
Wbrew zakładanym intencjom, szkolenia średniowiecznych fechtmistrzów doprowadziły raczej do pojawiania się domorosłych i nieprofesjonalnych "nauczycieli walk”, co ostatecznie nie szło w parze ze wzrostem bezpieczeństwa i rozwojem duchowym ówczesnych społeczności.

Po dyskusji i przerwie odbyła się druga sesja, której przewodniczył student Instytutu Filozofii UKSW Stanisław Puchniewicz. Pierwszy referat w tej części konferencji, zatytułowany Zastosowanie przemocy w walkach politycznych w Rzymie pod koniec lat 50-tych I w. p.n.e., wygłosiła mgr Katarzyna Całus z Akademii im. Jana Długosza w Częstochowie. Prelegentka przedstawiła, w jaki sposób przemoc stosowana była w starożytnym Rzymie pół wieku przed kalendarzowym początkiem nowej ery. Nieustanna walka, przekupstwa finansowe i inne formy przemocy, które związane były głównie z wyborami konsulów, nasiliły się szczególnie przed wyborami, jakie odbyły się w 52 roku przed Chrystusem. Niemal powszechne stało się wtedy zastraszanie obywateli i podburzanie plebsu, a nawet formowanie prywatnych oddziałów zbrojnych mających na celu zwalczanie przeciwników politycznych. W swoim wystąpieniu mgr Całus skupiła się przede wszystkim na działaniach Gnejusza Pompejusza Wielkiego, który został wówczas wybrany na urząd konsula. Przypuszcza się, że w latach $54-52$, by uzyskać w Cesarstwie dominująca pozycję, swoimi działaniami bardzo mocno pogłębił on społeczną destabilizację i anarchię. Skutkowało to zamieszkami w Rzymie, wzrostem przestępczości i okrucieństwa. Ostateczną konsekwencją przyzwolenia na polityczną przemoc było pogrążenie się Wiecznego Miasta w całkowitym chaosie.

Kolejna prelegentka - mgr Agnieszka Gralewicz z Instytutu Filozofii UKSW - wygłosiła referat zatytułowany Krwawa rewolucjakoniecznośc czy decyzja? W swoich rozważaniach pytała, czy przemoc wchodzi w istotę pojęcia rewolucji, a poszukując odpowiedzi, przywoływała stanowiska takich myślicieli i filozofów, jak: Albert Camus, Hannah Arendt, Aleksandr Kojève, Raymond Aron, Maurice 
Merleau-Ponty. Pokazywała, że wymienieni autorzy odróżniają rewolucję od buntu, który sam Camus traktował jako indywidualne doświadczenie pierwotne, a o którym Hannah Arendt twierdziła, że jest związany $z$ wyzwoleniem $i$ ugruntowaniem człowieka $w$ jego wolności. Rewolucja to $z$ kolei pewna gwałtowna zmiana i w sensie politycznym można wskazać na jej trzy wymiary: przyczynę, przebieg i kres. Rozpatrywana zaś może być na dwa sposoby - jako konieczność bądź jako decyzja. Wybór któregoś z tych sposobów wymaga odwołania się do wizji antropologicznej. W przypadku rewolucji wpisanej w sens dziejów (konieczność) człowiek-widz nie ponosi za nią odpowiedzialności. Uznanie rewolucji za decyzję człowieka (wybór) rodzi pytania o problem zła. Czy tkwi ono w człowieku? czy przemoc, będąca nieodłącznym elementem rewolucji, jest warunkiem zmian a może jedynie jej skutkiem ubocznym? Ryzykowne założenie sterowności rewolucji - przekonywała mgr Gralewicz - prowadzi do nieuniknionego zastąpienia początkowej potrzeby budowy nowego ładu świata przez konieczność uważnej kontroli struktur organizacji tak, aby rewolucja głosząca szlachetne idee, nie przerodziła się w kolejną, generującą niesprawiedliwość i przemoc, tyranię.

Nawiązujący znowu do doświadczeń historycznych referat Przemoc i alkohol - z badań nad szlachta Mazorwsza i Podlasia (XVI-XVII w.) zaprezentował mgr Emil Kalinowski z Wydziału Historycznego Uniwersytetu Warszawskiego. W wystąpieniu przedstawił materiały historyczne z XVI i XVII wieku dotyczące szlachty z terenu pogranicza Mazowsza i Podlasia - dawnej ziemi bielskiej. Prelegent pokazał, że pijaństwo szlachty w tym czasie było niemal przysłowiowe. Duża liczba karczm w miastach i wioskach niewątpliwie przyczyniała się do niezachowywania trzeźwości przez szlachciców. Na sejmikach nierzadko pijana szlachta podejmowała ważne społecznie decyzje i próbowała kierować wspólnotą. Taki rozrost patologii był możliwy także dlatego, że pijaństwo, choć potępiane, w powszechnej opinii nie stanowiło poważnego problemu. Dopiero mocno kompromitujące zachowania wywoływały niechęć i reakcje władzy. Ostatecznie ten 
społeczny problem nasilił się tak bardzo, że w Prawach konstytucyjnych i przywilejach Królestwa Polskiego z 1611 roku pojawiła się specjalna nota prawna: O ubiciu Szlachcica w karczmie, dotycząca pijackich zachowań szlachty. Mgr Kalinowski sugerował w swojej prezentacji, że zarówno problem pijaństwa szlachty, jak i wynikająca $z$ tego przemoc, anarchizacja i destabilizacja życia społecznego mogą być uważane za jedną z przyczyn erozji polskiego etosu narodowego, a w konsekwencji za przyczynę upadku Rzeczpospolitej.

Ostatni referat w sesji drugiej zaprezentowała mgr Katarzyna Gruszka z Uniwersytetu Łódzkiego, która swoje wystąpienie zatytułowała Przemoc w życiu publicznym na przyktadzie terroru stosowanego przez Viet Cong/WAL wobec ludności cywilnej w Wietnamie w 1968 roku. Prelegentka przedstawiła tragedię, jakiej w 1968 roku doświadczali cywilni mieszkańcy wietnamskiego miasta Hue. Władzę nad miastem przejęli wtedy partyzanci z Narodowego Frontu Wyzwolenia Wietnamu Południowego i Wietnamskiej Armii Ludowej. Wobec osób podejrzewanych o negatywny stosunek do komunizmu stosowali daleko idący terror. Działacze komunistyczni przygotowywali „czarne listy”, na których wypisane były osoby mające zostać poddane represjom. Powszechne stały się tortury, egzekucje, grzebanie żywcem, a gwałtu doświadczali zarówno ludzie katowani i mordowani, jak i żyjący w strachu obserwatorzy tych zdarzeń. Przemoc komunistów wobec ludności cywilnej wykraczała poza ramy czasowe bitwy o samo miasto Hue, a mimo to została w mediach przemilczana. Zbrodnie $\mathrm{z}$ wietnamskiego Hue ostatecznie do dzisiaj nie zostały właściwie nagłośnione, potępione i ukarane.

Sesji trzeciej konferencji dotyczącej przemocy w życiu publicznym przewodniczył student Instytutu Filozofii UKSW Mateusz Ustaszewski, członek KNSF. Pierwszy referat zatytułowany, Przemoc zródtem religii? Refleksja nad myśla René Girarda, wygłosił mgr Sergiusz Anoszko z Wydziału Teologicznego UKSW. Przybliżył słuchaczom poglądy francuskiego antropologa filozoficznego i historyka René Girarda, który stawiał tezę, że każda przemoc i każdy konflikt 
mają zawsze charakter społeczny. Człowiek jest często agresywny, ponieważ w jego naturze tkwi chęć rywalizacji, stanowiąca nieodłączny element przemocy. Pragnienie zawładnięcia, które charakteryzuje człowieka, wygasa dopiero wtedy, gdy człowiek posiądzie to, czego pragnie. Ten antropologiczny mechanizm dobrze opisuje teoria mimesis, której ostatni element stanowi ujawnienie uczuć. Gdy człowiek nie panuje nad uczuciami, dochodzi do niezdrowej rywalizacji i przemocy. W referacie została przedstawiona również Girardowska „teoria ofiary”, zgodnie z którą spontaniczne morderstwo jednego z członków społeczeństwa doprowadza do zgody i zjednoczenia się ludzi w sytuacji zagrożenia. W tym społecznym mechanizmie przekonywał Girard - przemoc staje się źródłem religii. Prelegent, polemizując z poglądami francuskiego myśliciela, dowodził, że teoria ta nie znajduje zastosowania $\mathrm{w}$ chrześcijaństwie, ponieważ Jezus Chrystus, czyli „ten, który się wstawia”, nie jest ofiarą w rozumieniu Girarda, stąd nie można zgodzić się na tezy proponowane przez filozofa. Źródłem chrześcijaństwa jako religii jest ofiarna miłość, a nie przemoc.

Kolejny referat to wystąpienie mgr Liliany Fabisińskiej z Akademii Pedagogiki Specjalnej im. M. Grzegorzewskiej w Warszawie, zatytułowany Przemoc rówieśnicza - poza prawem, poza kontrola? Prelegentka w swoim wystąpieniu skupiła się na problemie przemocy obecnej dziś w środowisku szkolnym. Zaznaczyła bardzo mocno, że agresja $\mathrm{w}$ zachowaniach dzieci i nastolatków jest zjawiskiem pozostającym niejako poza prawem, nie dopuszcza ono bowiem możliwości karania osób, które nie skończyły 13 roku życia. W przypadkach aktów przemocy dokonywanych przez nieletnich jako kara stosowane bywa wysyłanie dzieci do specjalnych placówek. Zazwyczaj nie przynosi to jednak spodziewanych pozytywnych rezultatów. Przywołane przez prelegentkę badania ujawniły, że 60\% nastolatków w wieku 11-17 lat było ofiarami agresji w szkole. Obecnie wiele negatywnych zachowań rówieśniczych ma miejsce w Internecie, co nie zawsze dostrzegają rodzice, nauczyciele i pedagodzy. Mgr Fabisińska 
przedstawiła szereg przykładów przemocy, w których czynniki ją wywołujące były od siebie diametralnie różne (wygląd, pochodzenie, kolor skóry, zamożność, choroba, płeć, ubiór, zainteresowania). Niestety problem ten jest często lekceważony przez nauczycieli, choć dzieci doświadczające zła rówieśniczego nierzadko wymagają pomocy psychologicznej. Niezaprzeczalny fakt wzmagania się problemu agresji wśród dzieci i nastoletniej młodzieży jednoznacznie wskazuje, że szkoła, choć powinna pełnić funkcję wychowawczą i opiekuńczą, nie zawsze zapewnia uczniom poczucie stabilności i bezpieczeństwa.

Trzeci referat pt. Gniew jako źródto przemocy w życiu publicznym. Politycznośc emocji wedtug Marthy C. Nussbaum wygłosił mgr Maciej Papierski z Instytutu Filozofii UKSW. Martha C. Nussbaum, nazywana filozofem emocji, krytykuje w swoich pracach utożsamianie zjawisk somatycznych towarzyszących emocjom z samymi emocjami. Proponuje intelektualną koncepcję emocji, w której odczuwanie jest formą myślenia, a emocje są sądami wartościującymi wobec tego, co człowiek uznaje za dobre i co jednocześnie pozostaje poza jego kontrolą. Sprzeciwiając się stoikom, którzy do emocji odnosili się z dużą rezerwą, Nussbaum twierdzi, że zawsze są one sygnałami zmuszającymi ludzi do introspekcji. Dlatego negując je, tłumiąc bądź pozbywając się ich, nie można dobrze żyć. Emocje dotyczą celów, które człowiek realizuje w społeczeństwie przy jednoczesnym wchodzeniu $\mathrm{w}$ relacje z ludźmi mającymi swoje własne cele. Mówiąc o polityczności emocji, filozofka zwraca uwagę na gniew, który powstaje, gdy ktoś celowo zagraża dobru będącemu w kręgu pragnień i zamierzeń drugiego człowieka. Mimo jednak właściwego uchwycenia emocji pamiętać należy, mówi Nussbaum, że w człowieku istnieje poważna skaza - inklinacja do zła. Ona jest źródłem gniewu, który żądając wyrównania rachunków w imię sprawiedliwości, może prowadzić do eskalacji nienawiści i zbrodni. Sposobem uniknięcia wpływu złych emocji jest uznanie, iż w ideę praworządności należy wpisać ideę miłosierdzia. Tylko dzięki temu społeczności mogą zrozumieć, iż 
sprawiedliwość polega nie tyle na karaniu zła, ile przede wszystkim na realizacji proporcjonalnego dobra.

Jako ostatni mówca konferencji wystąpił Łukasz Gołąb z Wydziału Filozofii Katolickiego Uniwersytetu Lubelskiego. Wygłosił referat zatytułowany Przemoc religijna u źródet Nowego Ateizmu poglady Sama Harrisa. Prelegent w swoim wystąpieniu przywołał stanowisko Sama Harrisa, jednego z przedstawicieli ruchu zwanego Nowym Ateizmem. Brytyjski ateista przekonuje w swoich pracach, że ludzie wierzący są ofiarami własnych imaginacji, a religia jest jarzmem, spod którego należy się wyzwolić. Jego zdaniem to właśnie religijny światopogląd, a nie natura człowieka, prowadzi do przemocy i terroru. Harris krytykuje wszystkie religie ponieważ - jak twierdzi - związek pomiędzy doktryną religijną a przemocą jest konieczny i trwały. Oczywiście jego krytyka religii nie neguje obecnej w człowieku potrzeby duchowości. Proponuje jednak, by zaspokoić ją nie religią, a różnymi formami laickich sposobów wewnętrznego samodoskonalenia (np. praktykami medytacyjnymi, ćwiczeniami, dietą). Przedstawiciele Nowego Ateizmu - mówił Łukasz Gołąb odrzucają religię jako nieracjonalną mitologię i nie dopuszczają możliwości merytorycznej dyskusji na temat Boga. Prelegent zauważył, że takie podejście jest formą przemocy stosowaną wobec ludzi o innym światopoglądzie. Polega ona na odmawianiu im prawa do wyrażenia swojego zdania i zaprezentowania swoich argumentów. Głoszony przez Nowy Ateizm sprzeciw wobec przemocy okazał się - konkludował mówca - kolejnym jej przejawem.

Koniec trzeciej sesji był jednocześnie ostatnim etapem całej konferencji. Po ciekawej dyskusji dotyczącej wygłoszonych referatów w ramach podsumowania, ks. dr hab. Jacek Grzybowski, opiekun Wydziałowy KNSF, zauważył, że słuchając tak wielu ciekawych wystąpień, można było zrozumieć, iż pytanie o przemoc jest ostatecznie pytaniem o antropologiczną wizję świata i człowieka. W zależności od przyjętej antropologii przemoc może albo zostać uznana za pewien przejaw tkwiącej w człowieku niegodziwości, albo zostać 
potraktowana jako niezależne od człowieka zło wpisane w sens dziejów. Referaty wygłoszone przez przedstawicieli kilku środowisk akademickich zaproszonych do udziału w konferencji w ciekawy i wieloaspektowy sposób zaprezentowały podjęty przez organizatorów temat, skłaniając zapewne słuchaczy do pogłębionej refleksji nad poruszanymi zagadnieniami.

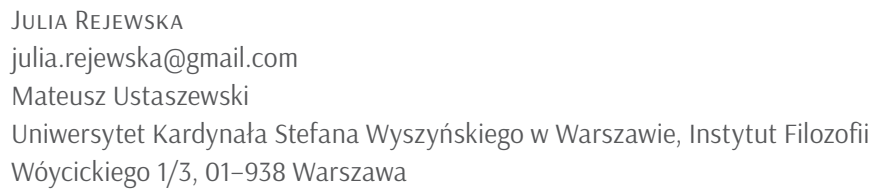

